\title{
INDUSTRI DENGAN BERBAGAI MASALAH YANG DIHADAPI DI SAAT SEKARANG INI
}

\author{
Oleh : Gurniwan Kamil Pasya*)
}

\begin{abstract}
Abstrak
Indonesia sebagai negara yang banyak mengalami berbagai masalah industri seperti lokasi industri yang berada di tengah pemukiman, menggeser lahan pertanian, pencemaran lingkungan, dan pemutusan hubungan kerja, menyebabkan keberadaan industri harus dikaji kembali jangan sampai masalah tersebut terus berlanjut, sehingga bukan keuntungan yang diperoleh melainkan kerugian bagi negara, pengusaha dan masyarakat. Karena itu, penanganan yang serius dari berbagai pihak perlu dilakukan terutama dari pemerintah sendiri seperti amdal yang jelas, pengawasan yang terus dilakukan, dan lokasi tidak mengganggu lahan pertanian yang produktif, terutama lokasi di pinggiran kota. Di samping itu, perlu juga meningkatkan dan melindungi industri rakyat dalam bentuk industri kecil dan kerajinan sebagai warisan budaya bangsa, agar jangan sampai diakui menjadi milik bangsa lain. Begitupula produk industri diprioritaskan untuk memenuhi kehidupan masyarakat banyak sebelum dilakukan ekspor, sehingga tidak semata-mata keuntungan yang dicari melainkan keuntungan dan kebutuhan masyarakat.

Kata kunci : lokasi industri; pencemaran, dan industri rakyat
\end{abstract}

*) Dr. Gurniwan Kamil Pasya, M.Si, adalah dosen Jurusan Pendidikan Geografi FPIPS UPI. 


\section{Pengantar}

Suatu negara dapat disebut sebagai negara maju apabila dilihat dari perkembangan industri dan teknologi yang dimilikinya, tetapi suatu negara disebut sebagai negara yang sedang berkembang apabila negara tersebut masih mengandalkan sektor agraris dan mengekspornya ke negara lain, begitupula teknologinya banyak yang masih berasal dari negara maju. Hal tersebut merupakan pandangan sebagian kecil untuk melihat kemajuan suatu negara, walaupun bukan merupakan ukuran yang mutlak. Indonesia sebagai negara yang sedang berkembang sangat sulit keluar dari berbagai masalah yang berhubungan dengan industri, di satu sisi industri memberikan masukan bagi pendapatan negara dan banyak menyerap tenaga kerja, di sisi lain nampaknya belum bisa mengatasi pencemaran atau kerusakan lingkungan yang diakibatkan oleh industri, berarti terdapat dua sisi yang saling bertentangan kita tinggal melihat sisi mana yang paling dominan, apakah lebih banyak keuntungan atau lebih banyak hal yang merugikan ? hal tersebut bukanlah pilihan apabila mengambil keuntungan dari industri tetapi hal yang merugikannya masih ada, kita harus memilih keuntungan adanya industri tanpa adanya hal yang merugikan seperti industri yang tanpa pencemaran dan industri mendukung kehidupan masyarakat yaitu industri yang bahan bakunya dihasilkan oleh masyarakat sendiri terutama mereka yang berada di sektor agraris. Peningkatan industri yang berbahan baku agraris pernah dilakukan dan dikembangkan pada saat Pelita I di awal tahun 1970-an, tetapi di awal abad 21 ini tampaknya industri di Indonesia sudah sangat beragam sekali, bahkan banyak industri yang bahan bakunya justru di impor dari negara lain, akibatnya terjadi ketergantungan terhadap negara tersebut. Permasalahan industri tidak hanya sampai di situ saja, banyak juga yang menyangkut hal lain, seperti : lokasi industri yang tidak sesuai dengan penempatannya seperti yang kita pelajari dalam geografi industri; banyaknya industri yang di relokasi ke negara lain akibat ekonomi biaya tinggi bagi pengusaha; banyaknya hasil industri negara lain yang masuk ke Indonesia dengan harga yang sangat murah, dan sebagainya. Dengan demikian, perlu kiranya kita turut memikirkan dan menanggapi keberadaan industri di dalam negeri sendiri untuk dapat menunjang kehidupan masyarakat dan perekonomian negara, untuk itu diperlukan 
suatu kebijakan pemerintah secara menyeluruh mengenai industri ini yang ditunjang oleh karyawan dan masyarakat sendiri. Selain itu, upaya penanaman modal asing di bidang industri, juga penanaman modal dalam negeri juga harus mendapat prioritas utama, dengan melibatkan bahan baku dari dalam negeri dan sumberdaya yang dimiliki.

\section{Lokasi Industri}

Penempatan lokasi industri dilihat dari sudut kepentingan pengusaha, tentu akan disesuaikan dengan biaya yang harus dikeluarkan, terutama biaya pengangkutan bahan baku dan pengangkutan hasil industri itu sendiri, tetapi bagaimana kondisi masyarakat dan wilayah apabila di tempat tersebut berdiri industri atau pabrik, begitupula industri kecil diusahakan masyarakat yang sulit untuk berkembang karena modal dan pemasaran yang sangat terbatas. Berikut ini beberapa masalah yang timbul dari lokasi industri. Misalnya,

1) Industri yang mendekati daerah pemasaran akan cenderung ditempatkan di pinggiran kota, mengingat bahan baku mudah untuk diperoleh dan dekat dengan pemusatan penduduk sebagai daerah pemasaran, seperti halnya di Pulogadung pinggiran kota atau sekitar kota Bandung di Ujungberung, Majalaya, Banjaran, dan lain-lain. Hal tersebut terjadi di awal tahun 1970-an, berdirinya pabrik-pabrik di sana banyak menggeser kepentingan masyarakat, yaitu lahan pertanian yang produktif diubah untuk kepentingan industri, sehingga memaksa para petani beralih mata pencaharian ke sektor jasa atau menjadi buruh industri. Akibat yang terjadi dari dipilihnya lahan pertanian untuk industri, antara lain :

a) Pemerintah setempat mempersilahkan membangun wilayah industri di pinggiran kota, menyebabkan bermunculan calo-calo tanah, yang akan membeli lahan pertanian dari petani dengan harga yang sedikit lebih tinggi dari harga standar, kemudian menjualnya kepada pengusaha dengan harga yang tinggi, apabila petani tidak mau untuk melepaskan lahannya maka dilakukan dengan berbagai cara agar lahan tersebut dapat dijual;

b) Pada mulanya petani merasa mendapat uang yang besar dari hasil penjualan lahan pertanian, tetapi di antara mereka banyak yang 
menggunakannya bukan untuk hal-hal yang produktif, malahan menjadi konsumtif. Di saat uang habis, maka muncul kebingungan untuk memenuhi kebutuhan hidup, sehingga barangbarang yang telah dibeli banyak dijual kembali dengan harga yang sangat murah, akikabtnya banyak yang jatuh miskin;

c) Walaupun di antara mereka banyak yang memanfaatkan uang tersebut untuk membuka usaha di bidang lain, tetapi tidak semuanya berhasil karena tidak dipersiapkan untuk memiliki keterampilan sesuai dengan usaha yang dilakukannya;

d) Buruh tani, sebagai masyarakat yang memiliki kelas sosial di bawah pemilik lahan pertanian, akan sulit bekerja di bidang industri, sehingga banyak di antara mereka yang bekerja dengan tidak menentu, seperti menjadi pekerja bangunan, pedagang asongan, tukang becak, kuli pasar, dan pekerjaan lain yang hanya membutuhkan tenaga kasar;

e) Produksi beras yang dihasilkan di dalam negeri menjadi menurun, karena lahan pertanian yang produktif telah beralih fungsi, sehingga di tahun-tahun selanjutnya Indonesia sulit untuk swasembada beras, bahkan untuk memenuhi kebutuhan dalam negeri hampr setiap tahun harus mengimpornya dari negara lain.

2) Industri yang mendekati bahan baku, seperti industri kayu lapis atau penggergajian, industri semen, industri yang berhubungan dengan pertambangan, dan sebagainya. Industri yang mendekati bahan baku seperti ini sangat rentan sekali terhadap kerusakan lingkugan. Misalnya,

a) Industri kayu lapis atau penggergajian kayu banyak dilakukan di wilayah yang memiliki hutan sangat luas seperti di Pulau Kalimantan atau di Pulau Sumatera. Akibat yang terjadi antara pengambilan kayu dan lahan menjadi hutan kembali tidak seimbang, malahan pengusaha hanya mengambil kayunya saja tanpa melakukan penanaman kembali, sehingga wilayah yang tadinya hijau dengan hutan yang lebat, sekarang hanya tinggal lahan-lahan yang terbuka, lebih parah lagi di wilayah tersebut terjadi kekurangan air di musim kemarau dan menyebabkan terjadinya banjir di wilayah lain di musim penghujan. Hal ini 
telah terjadi setiap tahun di Indonesia dengan banyaknya wilayah yang mengalami kekeringan di musim kemarau dan pada musim hujan mengalami banjir, akibat banyaknya sungai yang sudah tidak dapat menampung lagi air hujan, karena daerah resapannya sudah tidak ada lagi;

b) Industri yang berhubungan dengan pertambangan, terutama yang dilakukan oleh rakyat seperti di Propinsi Bangka-Belitung dianggap merusak lingkungan, karena menyebabkan permukaan tanah bagian atas menjadi gundul, mengingat timah di wilayah tersebut merupakan endapan sekunder. Sebelum dilakukan penambangan dengan menggunakan air, maka terlebih dahulu tumbuhan di permukaan tanah harus dibersihkan. Akibatnya pada wilayah yang telah dijadikan tempat penambangan setelah kandungan timahnya habis maka akan ditinggalkan dengan meninggalkan lahan yang gersang karena lapisan tanah bagian atas yang memiliki kesuburan telah habis pula.

c) Industri minyak goreng dengan bahan baku dari kelapa sawit yang diusahakan di Sumatera dan Kalimantan secara besarbesaran, tetapi tidak mendukung kebutuhan dalam negeri, karena pada saat-saat tertentu hilang atau berkurang di pasaran yang akibatnya harga menjadi naik. Para pengusaha tampaknya lebih senang menjual ke luar negeri mengingat harganya yang lebih tinggi dibandingkan harga jual di dalam negeri, keuntungan diraih sebesar-besarnya tanpa memperdulikan kepentingan masyarakat luas. Tidak sedikit pengusaha minyak goreng atau pengusaha perkebunan kelapa sawit, yang membuka hutan untuk memperluas areal perkebunan tanpa perhitungan sehingga menimbulkan kebakaran setiap tahun yang asapnya mengganggu kesehatan masyarakat, penerbangan, dan negara tetangga. Karena itu, penegakkan hukum bagi pelanggar harus jelas dan transparan, terutama dalam terjadinya kebakaran hutan atau hilangnya minyak goreng di pasaran,

3) Industri rakyat yang banyak terdapat di berbagai wilayah sebagai industri yang mendekati tenaga-tenaga terampil sulit untuk berkembang yang disebabkan oleh beberapa hal, antara lain : 
a) Industri batik sebagai karya dan budaya bangsa Indonesia hanya sebagian kecil yang mengalami perkembangan dan diakui secara nasional maupun international, tetapi sebagian besar hanya industri-industri kecil yang memiliki modal dan pemasaran terbatas sehingga sulit berkembang, bahkan banyak yang hanya tinggal kenangan, seperti industri batik tulis di Tasikmalaya dan Garut dengan gaya daerah bersangkutan banyak yang mengalami gulung tikar akibat munculnya batik printing yang dilakukan oleh pengusaha dengan modal yang kuat. Seperti kita ketahui bahwa batik di Tasikmalaya (mitra batik) sebagai bukti lahirnya koperasi di Indonesia yang dilakukan oleh Moh. Hatta saat itu, sehingga beliau dianugerahi sebagai bapak koperasi Indonesia. Sekarang ini tampaknya usaha batik yang perlu mendapat perhatian lebih dari pemerintah melalui Departemen Perindustrian, mengingat industri batik banyak dilakukan oleh masyarakat sebagai industri kecil, terutama dalam modal dan pemasaran di luar negeri, apalagi konon katanya batik Indonesia mendapat persaingan yang keras dari industri batik Malaysia yang dianggap telah melakukan hak patent bahwa batik merupakan produk budaya mereka. Dengan demikian, pemerintah perlu pula melakukan perlindungan terhadap batik sebagai warisan budaya sendiri.

b) Industri kerajinan yang banyak dipasarkan di tempat-tempat wisata seperti yang beraqsal dari Rajapolah Tasikmalaya. Kerajinan seperti ini walaupun berasal dari daerah yang memiliki banyak tenaga terampil dan dipasarkan di daerah lain, tetapi pemasarannya sangat sulit, karena barang yang dijual hanya sebagai cindera mata dan dibeli wisatawan hanya dalam jumlah yang sangat terbatas. Karena itu, perlindungan dan pemasarannya perlu mendapat perhatian sebelum diakui negara lain sebagai hasil budayanya.

c) Industri rakyat yang mendekati daerah pemasaran (di wilayah perkotaan) dalam bentuk industri makanan dengan bahan baku yang dihasilkan dari dalam negeri sangat terbatas, sehingga pemerintah perlu mengimpornya dari negara lain. Industri ini tidak lain menghasilkan kecap, tahu, dan tempe, dengan bahan baku kedelai 
yang diimpor dari Amerika Serikat, karena produksi dalam negeri pada tahun 2007 hanya sebesar 0,6 juta ton, sedangkan kebutuhan tersebut 1,6 juta ton, berarti sisanya harus membeli dari negara lain yaitu Amerika Serikat. Di akhir tahun 2007 negara pengimpor mengurangi jumlah produksi kedelai, akibatnya harga di pasaran menjadi naik, sehingga merupakan pukulan bagi pengusaha kecap, tahu dan tempe, akhirnya mereka terpaksa menaikan harga dan memperkecil barang yang dijualnya atau bahkan banyak pengusaha yang menghentikan produksi alias gulung tikar. Keadaan ini, memaksa pemerintah di awal tahun 2008 untuk menghapuskan bea masuk kedelai impor dan membuka pertanian kedelai di berbagai daerah. Tetapi meningkatkan kedelai produksi dalam negeri melalui pertanian yang dilakukan masyarakat akan sulit dilakukan, karena para petani telah terbiasa dengan budaya menanam padi, sehingga apabila melakukan diversifikasi pertanian seakan-akan tidak mendapatkan kepastian antara biaya pemeliharaan dan nilai jual yang akan diperoleh. Karena itu, sebelum penanaman kedelai diserahkan kepada para petani, pemerintah terlebih dahulu membuka lahan pertanian atau memanfaatkan lahan yang ada di berbagai daerah, terutama yang telah mengalami kerusakan akibat penebangan hutan baik untuk industri atau yang dilakukan secara liar. Lahan-lahan tersebut diusahakan dan ditanami oleh pemerintah sendiri melalui Departemen Pertanian, hasilnya sesuai dengan harga yang ditetapkan pemerintah. Selain itu terdapat pula industri yang mendekati daerah pemasaran dengan bahan baku impor seperti industri kue dengan bahan baku terigu, mereka termasuk industri yang turut terpukul dengan naiknya biaya produksi seperti, naiknya harga bahan bakar, naiknya terigu. Dalam hal ini di Indonesia tidak ada budaya menanam terigu dan masih tetap mengandalkan impor dari negara lain, akibatnya tidak berdaya terhadap kenaikan bahan baku tersebut. Industri kecil atau industri rakyat yang sangat terpukul adalah industri tahu seperti yang terjadi di wilayah kabupaten Sumedang, yaitu naiknya semua biaya produksi seperti : bahan bakar minyak tanah yang sulit didapatkan kalaupun ada harganya sudah mahal, apabila diganti dengan gas itupun sulit juga didapatkan dan juga mengalami 
kenaikan, bahan bakar digunakan untuk mematangkan kedelai sebelum digiling, kemudian setelah kedelai hancur maka akan dipanaskankan lagi melalui perebusan yang akhirnya dipadatkan, setelah dipotong-potong menjadi beberapa bagian tahu yang sesuai dengan ukuran, maka dijual dalam bentuk tahu goreng yang memerlukan bahan bakarpula; bahan baku kedelai jelas mengalami kenaikan; minyak goreng juga mengalami kenaikan. Akibatnya usaha kecil seperti tahu mendapatkan tekanan secara terus menerus yang menyebabkan harganya di pasaran menjadi naik, sehingga yang biasa menjadikan tahu sebagai makanan segan untuk membelinya, karena dianggap mahal.

\section{Industri dan Lingkungan}

Industri yang lokasinya di sekitar perkotaan banyak menimbulkan masalah, terutama yang menghasilkan bahan pencemar dalam bentuk limbah cair dan asap industri. Pencemaran air limbah industri sekarang ini diketahui setelah dilakukan penelitian di teluk Jakarta, yang dilakukan oleh tiga industri besar dan satu industri pemerintah, bukan tidak mungkin terjadi penyakit yang pernah melanda Jepang, yaitu penyakit Minamata. Pada mulanya industri yang ditempatkan di pinggiran kota jauh dari pemukiman penduduk, masalah pencemaran belum begitu dirasakan, tetapi sejalan dengan pertumbuhan penduduk dan perkembangan kota menyebabkan sekarang ini lokasi pabrik berada di tengah-tengah pemukiman, sehingga berbagai masalah muncul antara lain seperti,

1) Limbah cair industri tektill dari hasil pencelupan kain banyak yang langsung dialirkan ke sungai, akibatnya perairan banyak yang tercemar, selain banyak mahluk hidup yang mati juga mencemari tanah pertanian sehingga kesuburannya menjadi berkurang, bahkan di wilayah industri sekitar kota Bandung yaitu yang menjadi langganan banjir di musim penghujan, air limbah bercampur dengan banjir yang mengakibatkan gatal-gatal dan penyakit kulit. Hal ini, akibat dari berbagai hal antara lain :

a) kurang berfungsinya IPAL (Instalasi Pengolahan Air Limbah) atau tidak memilikinya, bahkan IPAL tidak difungsikan pada saat 
hujan lebat sehingga limbah dibuang bersama-sama dengan air hujan;

b) kurangnya pengawasan terhadap industri bersangkutan;

c) sanksi yang lemah bagi industri yang melakukan pencemaran.

2) Asap pabrik menyebabkan penyakit gangguan pernafasan bagi penduduk yang berada di sekitar industri, bahkan naiknya harga minyaktanah menyebabkan banyak industri yang mengganti dengan bahan bakar batubara, akibatnya lebih parah lagi yaitu dengan munculnya asap yang pekat pada cerobong pabrik disertai dengan bau yang menyengat. Hal ini disebabkan industri tersebut tidak memiliki filter atau penyaringan asap untuk menetralkannya, dan sebagai bukti kurangnya pengawasan terhadap batas maksimal asap pabrik yang diperbolehkan.

3) Masyarakat yang bermukim di sekitar pabrik mengalami kekurangan air, karena industri akan banyak memerlukan air yang diambil dari air tanah permukaan tanpa adanya ijin dan pengawasan dari Direktorat Geologi Tata Lingkungan. Kalaupun industri menyediakan air bagi masyarakat, itupun sangat terbatas dan tidak mencukupi untuk kebutuhan minimal, akibatnya sering terjadi konflik antar masyarakat maupun masyarakat dengan pihak pengusaha.

\section{Industri dan Tenaga Kerja}

Industri bagi Indonesia merupakan salah satu jalan keluar untuk mengatasi angka pertumbuhan penduduk yang menyebabkan angkatan kerja semakin bertambah, sehingga sektor industri banyak menyerap tenaga kerja dibandingkan dengan sektor agraris. Tetapi sekarang ini setelah terjadinya krisis ekonomi Indonesia tahun 1998, tampaknya kondisi industri terus mengalami keterpurukan dengan tidak mengalami perbaikan sampai sekarang, akibatnya banyak tenaga kerja industri yang mengalami pemutusan hubungan kerja (PHK), sehingga sektor industri menjadi sebaliknya, bukan menyerap banyak tenaga kerja melainkan sektor yang banyak menimbulkan pengangguran baru. Berikut ini, beberapa masalah yang industri yang berhubungan dengan tenaga kerja, antara lain, 
1) Berdirinya industri di suatu wilayah pada mulanya memberi harapan bagi masyarakat sekitarnya untuk bekerja sebagai karyawan. Tetapi kebutuhan tenaga kerja industri memerlukan sumberdaya manusia yang terampil dan terdidik, apabila tidak dapat dipenuhi di wilayah bersangkutan, maka akan mendatangkan tenaga kerja dari wilayah lain, sehingga tenaga kerja setempat tidak terserap sesuai dengan harapan, akibatnya dapat menimbulkan konflik antara penduduk asli dengan penduduk pendatang. Lebih parah lagi apabila sumberdaya manusia yang dibutuhkan tersedia, tetapi industri mendatangkannya dari wilayah lain, sumberdaya manusia setempat diabaikan;

2) Banyak industri berbahan baku impor, di saat terjadi kenaikan harga bahan baku, maka industri kesulitan menjual hasil produksinya, sehingga untuk menekan biaya produksi yang salah satunya melalui pengurangan tenaga kerja, bahkan banyak industri yang berhenti produksi, antara lain industri rakyat dalam bidang usaha tahu dan tempe; industri tektill; industri kimia dasar, dan lain-lain.

3) Untuk meningkatkan kesejahteraan buruh, maka pemerintah memberlakukan UMR (Upah Minimum Regional) yang diberbagai daerah memiliki standar berbeda-beda, tetapi bagi pengusaha hal ini tidak semuanya dapat dilaksanakan, sehingga industri diharapkan berjalan sebagaimana mestinya. Tetapi kenyataannya menjadikan tuntutan karyawan secara meluas, sehingga terjadi demonstrasi terhadap pengusaha untuk menyesuaikan upah sesuai UMR, apabila kondisi keuangan mencukupi maka dapat dilakukan musyawarah, jika tidak maka industri akan berhenti berproduksi, melalui PHK, merumahkan karyawan, mengurangi karyawan dan lain-lain. Banyaknya tuntutan bagi pengusaha PMA (Penanaman Modal Asing) tentu akan merepotkan usaha mereka, apabila dirasakan tidak sesuai dengan keuntungan yang mereka peroleh, maka daripada melanjutkan produksi di Indonesia, akan lebih baik memindahkan lokasi industrinya ke negara lain yang ongkos produksinya lebih rendah. Akibatnya pengangguran baru akan bertambah di Indonesia, kerugian berada di pihak karyawan dan negara mengalami krisis kepercayaan dari pengusaha asing. 
4) Pengusaha banyak yang tidak menyenangi munculnya Serikat Pekerja di dalam industrinya, karena beranggapan dapat mengganggu jalannya produksi, sehingga karyawan akan diawasi secara sepihak agar mereka tidak terlibat dalam organisasi tersebut. Apabila terdapat karyawan yang menggalang munculnya Organisasi Serikat Pekerja, maka tidak sedikit pengusaha yang melakukan tekanan bahkan PHK secara sepihak agar karyawan tunduk kepada kemauan pengusaha. Tentu hal ini tidak diharapkan, karena bagaimanapun hak berserikat dilindungi oleh Undang-Undang, sehingga jangan sampai karyawan dieksploitasi tanpa memperhatikan hak mereka.

5) Pemutusan hubungan kerja dapat saja terjadi apabila hasil produksinya kurang diminati, seperti halnya yang terjadi pada PT. Dirgantara Indonesia (PT. D.I) di Bandung, banyak melakukan PHK karena perusahaan beranggapan sudah tidak dapat memenuhi lagi kewajibannya untuk membayar karyawan, di samping itu karyawan menuntut hak mereka untuk mendapatkan tunjangan sesuai dengan peraturan yang berlaku. Sampai saat ini tuntutan karyawan tidak seluruhnya terpenuhi, akibatnya demonstrasi mantan karyawan terus berlanjut dan tidak jelas kapan semuanya dapat diselesaikan tanpa adanya pihak-pihak yang dirugikan.

\section{Harapan terhadap Industri}

Berdirinya industri di suatu negara dapat dijadikan salah satu indikator kemajuan negara bersangkutan, sehingga melalui industri maka negara akan diuntungkan dengan adanya pemasukan melalui pajak, devisa, mengurangi pengangguran, dan lain-lain. Karena itu, untuk mendukung industri, diperlukan stabilitas ekonomi, politik dalam negeri dan penegakkan hukum yang sesuai dengan Undang-Undang yang berlaku seperti Undang-Undang PMA, Undang-Undang Ketenagakerjaan (perburuhan), Undang-Undang Lingkungan Hidup, dan lain-lain. Adapun harapan bagi industri untuk kemajuan negara antara lain,

1) Pembenahan lokasi industri yang sudah berada di tengah-tengah pemukiman dengan mengurangi dan menghilangkan dampak lingkungan yang ditimbulkannya; 
2) Mempersiapkan wilayah-wilayah yang dijadikan lokasi industri jauh dari lokasi pemukiman, dengan tidak mengorbankan lahan pertanian yang produktif;

3) Produksi yang dihasilkan suatu industri apabila sangat dibutuhkan masyarakat, maka harus dijadikan prioritas utama, baru kemudian untuk memenuhi kebutuhan ekspor;

4) Hutan yang habis ditebang untuk kebutuhan industri dan kebutuhan lain, perlu dikembalikan dengan mewajibkannya kepada pengusaha untuk menhutankan kembali dan menindak tegas kepada mereka yang melakukan pelanggaran terhadap batas-batas wilayah hutan;

5) Industri yang didirikan di suatu wilayah harus melengkapi Amdal yang dilakukan oleh lembaga independent, bukan amdal yang dibuat ataupun pesanan pengusaha, sehingga industri yang berdiri adalah industri yang ramah lingkungan;

6) Meningkatkan sumberdaya dalam negeri sebagai bahan baku industri untuk menggantikan bahan baku impor, sehingga ketergantungan terhadap bahan baku impor dapat dihilangkan. Bahan baku industri diharapkan dari hasil agraris atau yang dihasilkan oleh masyarakat;

7) Pemerintah membuka sekolah-sekolah menengah kejuruan yang mempersiapkan lulusannya menjadi tenaga kerja siap pakai untuk memenuhi kebutuhan sumberdaya manusia di bidang industri, di samping untuk melengkapi sekolah-sekolah yang telah ada. Selain itu dibuka pula sekolah-sekolah yang mempersiapkan pengadaan dan pengelolaan bahan baku industri;

8) Pemerintah mempersilahkan PMDN dan PMA untuk membuka industri di berbagai daerah yang banyak menyerap tenaga kerja setempat, bukannya yang banyak menggunakan robot industri untuk menggantikan tenaga manusia;

9) Pemerintah membuka pasar dalam negeri dan pasar international bagi industri-industri rakyat;

10) Melindungi karya sebagai budaya bangsa dari penjiplakan dan pengambilalihan oleh negara lain sebagai hasil karya mereka, seperti batik; kesenian tradisional; lagu daerah; dan lain-lain; 
11) Menggugat negara yang mengakui karya sebagai budaya bangsa Indonesia sebagai hasil karya budaya mereka ke mahkamah international;

12) Menggalakkan industri pariwisata untuk menambah devisa negara dan kehidupan masyarakat yang terlibat di dalamnya.

\section{Penutup}

Kita sebagai negara agraris untuk memenuhi kebutuhan beras dan kedelai dalam negeri harus melakukan impor dari negara lain, padahal wilayah kita masih sangat luas apalagi banyak lahan-lahan kosong yang tidak produktif di luar Jawa untuk dijadikan lahan agroindustri melalui program pemerintah lintas departemen dan dikelola oleh pemerintah sendiri untuk kepentingan masyarakat. Selain itu, Indonesia memerlukan relokasi industri ke luar pulau Jawa, sehingga tidak terjadi pemusatan industri di pulau ini. Adapun industri yang diperlukan adalah industri yang berbahan baku agraris selain hasil produknya untuk memenuhi kebutuhan dalam negeri, juga untuk memenuhi kebutuhan ekspor. Dari hal ini, maka tercipta lapangan kerja industri yang banyak menyerap tenaga kerja, sehingga transmigrasi yang diberangkatkan ke luar pulau Jawa tidak untuk menjadi masyarakat agraris sebagai petani semata-mata, melainkan menjadi tenaga kerja agroindustri. Mereka yang dikirim sebagai transmigran adalam mereka sebagai tenaga kerja trampil dan terdidik sesuai dengan kebutuhan. 